\title{
Infusions of Casein Hydrolyzates into the Mammary Gland Disrupt Tight Junction Integrity and Induce Involution in Cows
}

\author{
A. Shamay, ${ }^{*}$ F. Shapiro, ${ }^{*}$ G. Leitner, $\dagger$ and N. Silanikove* \\ *Agricultural Research Organization (ARO), the Volcani Center \\ Institute of Animal Science, P.O. Box 6, Bet Dagan, 50250 Israel \\ †Kimron Veterinary Institute, P.O. Box 6, Bet Dagan, 50250 Israel
}

\section{ABSTRACT}

Milk stasis triggers local stimuli, which make the tight junctions leak and trigger involution. The aim of the study was to test the hypothesis that casein hydrolyzates compromise tight junction integrity and dry-off milk secretion in dairy cows. Six repeated doses of casein hydrolyzates after each milking during $3 \mathrm{~d}$ caused drastic changes in mammary secretion and composition, which were associated with irreversible cessation of milk secretion. No such changes were recorded in the control glands that had been treated with nonhydrolyzed casein. Treatment with casein hydrolyzates disturbed tight junction integrity within $8 \mathrm{~h}$ (as indicated by changes in $\mathrm{Na}^{+}$and $\mathrm{K}^{+}$concentrations), reduced the concentrations of lactose precipitously, activated the plasmin activator-plasminogen-plasmin system, and induced the secretion of immunoglobulin type $\mathrm{G}$ and lactoferrin. At the end of the 3-d treatments, we stopped milking the experimental and control glands. Milk composition $19 \mathrm{~d}$ later was similar in the experimental and control glands and was consistent with the composition expected in fully involuted glands. We conclude that casein hydrolyzates are among the milkborne factors that cause the disruption of tight junction integrity and induce involution in cows. The process induced by casein hydrolyzate was more rapid and synchronized than the involution induced at drying-off.

(Key words: involution, mammary gland, secretion, tight junction)

Abbreviation key: $\mathbf{C N H}=$ casein hydrolyzate, $\mathbf{L f}=$ lactoferrin, $\mathbf{P A}=$ plasmin activator, $\mathbf{T} \mathbf{J}=$ tight junction .

\section{INTRODUCTION}

Enzymatic hydrolysis of casein $(\mathbf{C N})$ liberates peptides that may contribute to the health and proper de-

Received July 23, 2002.

Accepted November 6, 2002.

Corresponding author: N. Silanikove; e-mail: nsilanik@agri.huji. ac.il. velopment of young (FitzGerald, 1998) and serve as local regulators of mammary gland function (Silanikove et al., 2000; Shamay et al., 2002). A peptide derived from the activity plasmin on $\beta$-CN (fraction 1-28) downregulates milk secretion in cows and goats; its activity was correlated with its ability to block potassium channels in the apical membranes of mammary epithelia (Silanikove et al., 2000). In goats, injection of casein hydrolyzates (CNH) into the udder induced a local inflammatory response and loss of tight junction (TJ) integrity, followed by rapid drying-off mammary secretion (Shamay et al., 2002). As such events also characterize the involution induced by cessation of milking in cows and goats (Olivier and Smith, 1983; Hurley, 1989; Capuco and Akers, 1999), it was suggested that an artificial increase of the $\mathrm{CNH}$ concentration in the udder mimics the natural phenomenon. The process induced by $\mathrm{CNH}$ was more rapid and synchronized than that induced at drying-off (Shamay et al., 2002).

The serine protease, plasmin, is the predominant protease in milk and is known to produce boiling-resistant peptides (proteose-peptones) from $\beta$-CN and $\alpha$ s1- and $\alpha$ s2-CN (Politis, 1996). Plasmin in milk is found mainly in its inactive form, plasminogen, of which the conversion to plasmin is modulated by plasminogen activators (PA; Politis, 1996). The PA-plasminogen-plasmin system is involved in control of milk secretion and tissue remodeling during involution (Ossowski et al., 1979; Politis, 1996). We have shown that both the antisecretory properties of $\beta$-CN fraction 1-28 and the involuting properties of $\mathrm{CNH}$ are related to the activity of the PAplasminogen-plasmin system in milk (Silanikove et al., 2000; Shamay et al., 2002). However, only a modest increase in plasmin activity is required for activation of the antisecretory properties of $\beta$-CN fraction 1-28 (Silanikove et al., 2000), whereas the involution induced either by CNH (Shamay et al., 2002) or at the drying-off of mammary secretion was associated with a dramatic increase in plasmin activity (Aslam and Hurley, 1997; Athie et al., 1997). Consequently, the concentration of natural $\mathrm{CNH}$ (i.e., proteose peptones) increased dramatically in the mammary secretion of involuting goats (Shamay et al., 2002). 
There is no information on the effects of $\mathrm{CNH}$ on mammary secretion in cows. The objectives of the present study were to test the hypotheses: 1) that introducing $\mathrm{CNH}$ to the mammary gland disrupts epithelial cell TJ integrity, and induces dry-off of milk secretion in the treated glands, and 2) that this treatment imitates and accelerates the involution induced at drying-off.

\section{MATERIALS AND METHODS}

\section{Preparation of Casein Hydrolyzate}

Commercial bovine CN (Sigma) was dissolved (100 $\mathrm{g} / \mathrm{L})$ in $25 \mathrm{mM}$ Tris-buffer, $\mathrm{pH} 8$ and digested with tryp$\sin (500 \mathrm{U} / \mathrm{L})$ for $4 \mathrm{~h}$ at $37^{\circ} \mathrm{C}$. The solution was then acidified to $\mathrm{pH} 4.7$ with $\mathrm{HCl}$, and the nondigested $\mathrm{CN}$ was pelleted by centrifugation. The supernatant was boiled for $15 \mathrm{~min}$, cooled to room temperature, and adjusted to $\mathrm{pH} 7$ with $\mathrm{NaOH}$ solution. Material that had not dissolved under these conditions was removed by centrifugation and discarded, and the $\mathrm{CNH}$ solution was sterilized by passage through a $22-\mu \mathrm{m}$ sterile filter and kept frozen pending use. The typical protein concentration in the $\mathrm{CNH}$ solution (as measured by the Bradford method) was $20 \mathrm{mg} / \mathrm{ml}$. No measurable activity of PA, plasminogen, or plasmin was found in the CHN preparation administered to the udder.

Control solution was prepared as follows: Trypsin was deactivated by boiling at $100^{\circ} \mathrm{C}$ for $30 \mathrm{~min}$. The commercial $\mathrm{CN}$ was then treated with the inactivated trypsin solution as described above. The pelleted CN was dissolved $(20 \mathrm{mg} / \mathrm{ml})$ in $25 \mathrm{~m} M$ Tris-buffer, $\mathrm{pH} 8$, adjusted to $\mathrm{pH} 7$ with $\mathrm{NaOH}$, and sterilized and stored as described above. The osmotic pressure of the experimental and control solutions was $400 \mathrm{mOsmol} / \mathrm{kg}$.

\section{Animals and Their Maintenance}

The eight cows used in these experiments were multiparous (second, third, or fourth lactation) lactating and pregnant (last trimester) Holsteins that were scheduled for dry-off treatment (i.e., they were $\sim 300$ DIM). The cows selected for the experiment had SSC of $<300,000 \mathrm{cell} \mathrm{s} / \mathrm{ml}$. The cows were fed a typical Israeli TMR that comprised $65 \%$ concentrates and $35 \%$ forage and contained $17 \%$ protein throughout the trial. The cows were milked three times daily, at 0500,1300 , and $2000 \mathrm{~h}$, and produced $\sim 30 \mathrm{~L}$ milk per day. The composition of the mammary secretion from each quarter was recorded for $3 \mathrm{~d}$ before the treatment.

\section{Experimental Procedures}

A single dose of the $\mathrm{CNH}$ preparation $(67.5 \mathrm{mg}$ per $15 \mathrm{ml}$ as determined both by the spectrometric and the
macro-Kjeldhal assays and with absorbance of 20,000 at $280 \mathrm{~nm}$ ) was injected with a thin, rounded plastic needle, through the teat canal, into the cistern of two single glands (quarters) of each cow (i.e., 16 glands) after the morning milking. The contralateral quarters in each cow were treated with the same volume of the control solution. This procedure was repeated after the afternoon milking and similarly on the next $2 \mathrm{~d}$ (i.e., six postmilking doses over $3 \mathrm{~d}$ ). At the time of the evening milking on those days, the cows were not taken to the milking parlor and were not milked nor treated. The switch from thrice daily milking to twice daily milking may have reduced milk yield by $10 \%$, but for such a short period, milk composition was most likely not affected (Sorensen et al., 2001). After the last treatment, the cows were not milked throughout the dry period ( $\sim 60 \mathrm{~d})$, and milking was resumed in the next lactation cycle. Mammary secretions ( $100 \mathrm{ml})$ from each gland were collected and sampled at each dosing. In addition, a sample was taken from each gland daily at 0600 , for $3 \mathrm{~d}$ before the treatment, and on d 4, 10, and 19 after the cessation of treatments.

Analytical methods. The concentration of protein in the $\mathrm{CNH}$ preparation was determined by a spectrometric assay (Vernon and Bernlohr, 1977), by the macroKjeldhal method $(\mathrm{N} \times 6.35)$, and with absorbance at $280 \mathrm{~nm}$. The concentrations of total protein, whey proteins, total casein, and proteose peptone in mammary secretions were determined as described by Shamay et al. (2000). Enzyme-linked immunoassays were used for the determination of albumin (Stelwagen et al., 1994), lactoferrin (Lf) (Shuster and Harmon, 1996), and IgG (Kummer et al., 1992) concentrations. The activities of PA, plasminogen, and plasmin in milk were determined as described by Silanikove et al. (2000). Lactose concentration was determined enzymatically according to Shapiro et al. (2002). Mammary secretions were prepared for mineral (Na, K, Ca, Mg, P, and S) analysis as described by Shamay et al. (2000), and the concentrations of these minerals were measured with an Inductively Coupled plasma-atomic emission spectrometer (Spectro, Germany).

Statistical analysis. The datasets of this study were analyzed using repeated measures analysis (SAS PROC MIXED) modeling correlated residuals within cow (SAS, 1988). The analysis concentrated on the effects of treatment, day, and treatment $\times$ day interactions. The effect of parity and DIM were not significant $(P>0.25)$ and, therefore, were not included in the analyses presented here.

The model used was

$$
\mathrm{Y}_{\mathrm{ijkm}}=\mu+\mathrm{C}_{\mathrm{i}}+\mathrm{T}_{\mathrm{j}}+\mathrm{T}_{\mathrm{j}} \mathrm{D}_{\mathrm{k}}+\mathrm{Q}_{\mathrm{m}}\left(\mathrm{T}_{\mathrm{j}} \mathrm{C}_{\mathrm{I}}\right)+\mathrm{e}_{\mathrm{ijkm}},
$$


where $Y_{\mathrm{ijkm}}$ is the variable within cow, treatment, quarter, and day, $\mathrm{C}_{\mathrm{i}}$ is the cow class effect, $\mathrm{T}_{\mathrm{j}}$ is the treatment class effect, $D_{k}$ is the day class effect, $T_{j} D_{k}$ is the treatment $\times$ day interaction effect, $\mathrm{Q}_{\mathrm{m}}\left(\mathrm{T}_{\mathrm{j}} \mathrm{C}_{\mathrm{I}}\right)$ is the quarter within cow treatment error term for treatment effect; and $\mathrm{e}_{\mathrm{ijkm}}$ is the residual error.

Covariance between residuals within cow was modeled either as compound symmetry or as heterogeneous compound symmetry (SAS, 1988). Analyses relative to first treatment infusion used observations from the first 8-h (0.3-d) sampling and onward with pooled observations made before infusion as a covariate. Running this model using general linear model procedures and type III mean squares (SAS, 1988) yielded similar results to those obtained by the repeated measures analysis using either the compound symmetry or the heterogeneous compound symmetry analysis of residuals covariance.

\section{RESULTS}

\section{Volume, Appearance, and Osmotic Components}

Repeated doses of $\mathrm{CNH}$ induced precipitous dry-off of mammary gland secretion in the treated gland, whereas the control gland maintained its milk secretion. At the third day posttreatment, the scanty mammary secretion collected from the treated gland (100 to $300 \mathrm{ml}$ compared with a typical initial volume of $\sim 2.5 \mathrm{~L}$ ) was watery, fat-free, turbid (serum-like), and contained numerous amount of leukocytes (> then $5 \times 10^{6} / \mathrm{ml}$ ), mostly (90\%) in the form of polymorphonuclear neutrophils. This type of secretion resembled the secretion collected from the control glands at 10 and $19 \mathrm{~d}$ postmilking.

The concentration of lactose dropped precipitously in the treated glands, whereas in the control glands, it dropped only after cessation of milking (Figure 1). The drop in lactose was significant after the first milking $(0.3 \mathrm{~d})$, by $\mathrm{d} 1$ it had dropped to $\sim 50 \%$ of its initial concentration $(\sim 120 \mathrm{mmol})$, and by $\mathrm{d} 2$ and 3 , it was down to one-sixth of the initial concentration. In the control glands, after $4 \mathrm{~d}$ of dry-off (i.e., at d 7 of the experiment), lactose had dropped to $\sim 50 \%$ of the initial concentration. At $d 13$ and 22, the concentration of lactose was $\sim 20 \mathrm{mmol}$ in both the control and experimental glands (Figure 1).

In the experimental glands, the concentration of $\mathrm{Na}^{+}$ rose precipitously following the first treatment, whereas that of $\mathrm{K}^{+}$dropped precipitously (Figure 1). In the control glands, equivalent changes were observed only following cessation of milking. At d 13 and 22 of the experiment, the $\mathrm{Na}^{+}(\sim 120 \mathrm{mmol})$ and $\mathrm{K}^{+}(\sim 12 \mathrm{mmol})$ concentrations in the control and experimental glands were similar (Figure 1).
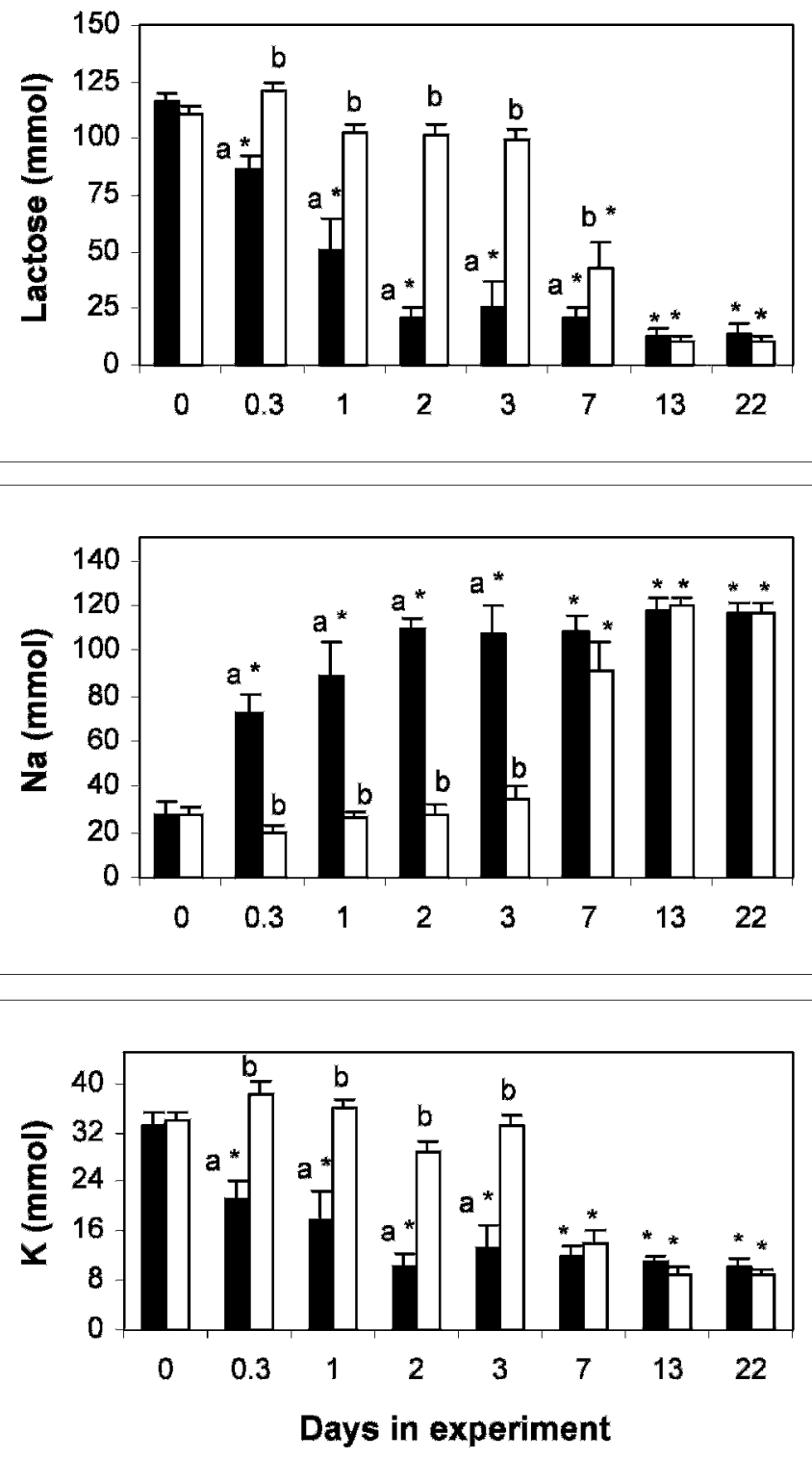

Figure 1. Effect of repeated dose of $\mathrm{CNH}$ and drying-off on lactose, $\mathrm{Na}^{+}$, and $\mathrm{K}^{+}$concentrations in mammary secretion. *Values are significantly different from the pretreatment values $\left(P<10^{-2}\right.$ to $\left.10^{-4}\right)$.

${ }^{a, b}$ Experimental values (filled bars) are significantly different from the control (open bars; $P<10^{-2}$ ).

\section{PA-Plasminogen-Plasmin System}

PA activity at the start of the experiment was $\sim 1100$ $\mathrm{U} / \mathrm{ml}$ (Figure 2). In the experimental glands, the PA activity rose significantly after the first treatment, and activities at the highest range ( 3200 to $3500 \mathrm{U} / \mathrm{ml}$ ) were measured at $\mathrm{d} 1,2,3$, and 7 to the experiment; on $\mathrm{d} 13$, the PA activity dropped significantly and fell further, to $\sim 1200 \mathrm{U} / \mathrm{ml}$ on $\mathrm{d} 22$. In the control glands, a nadir in 

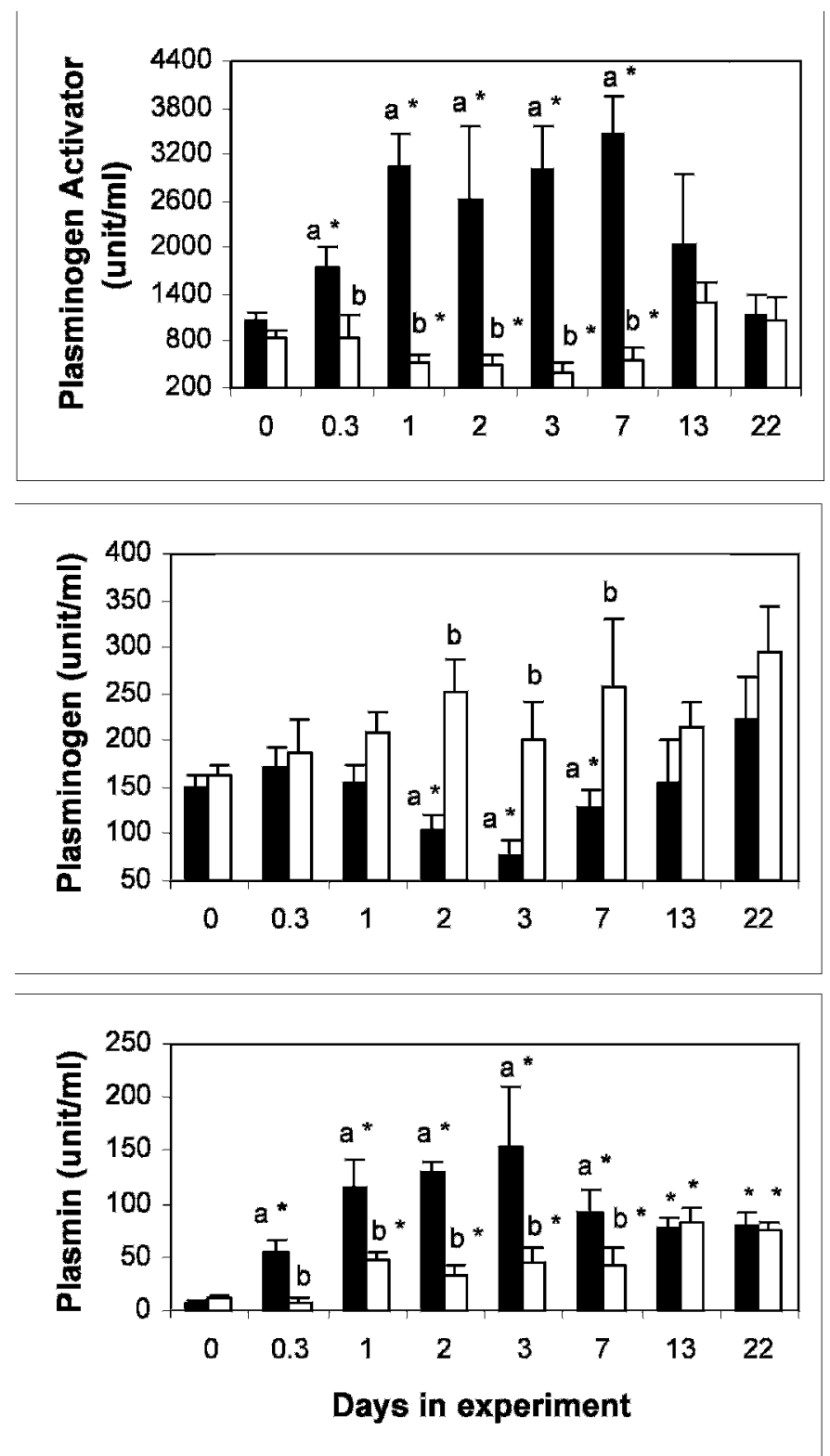

Figure 2. Effect of repeated dose of $\mathrm{CNH}$ and drying-off on plasminogen activator (PA), plasminogen, and plasmin activities in mammary secretion. One unit of PA, plasminogen, or plasmin activity was defined as the amount of enzyme producing a change in absorbance of 0.001 in $1 \mathrm{~min}$ at $37^{\circ} \mathrm{C}$ and $405 \mathrm{~nm}$. *Values are significantly different from the pretreatment values $(P<0.01)$. ${ }^{\mathrm{a}, \mathrm{b}}$ Experimental values (filled bars) are significantly different from the controls (open bars; $P<0.01$ ).

PA activity (400 to $600 \mathrm{U} / \mathrm{ml}$ ) was observed on $\mathrm{d} 1,2$, 3 , and 7 of the experiment; it was followed by a rise to $\sim 1200 \mathrm{U} / \mathrm{ml}$ on $\mathrm{d} 13$ and 22 (Figure 2).

Plasmin activity at the start of the experiment was $\sim 5.5 \mathrm{U} / \mathrm{ml}$ (Figure 2). In the experimental glands, the plasmin activity rose significantly after the first treatment, and activities in the highest range (120 to 150
$\mathrm{U} / \mathrm{ml}$ ) were measured on $\mathrm{d} 1,2$, and 3 of the experiment, after which it fell to $\sim 100 \mathrm{U} / \mathrm{ml}$ on $\mathrm{d} 7,13$, and 22 . In the control glands, plasmin activity rose to $\sim 50 \mathrm{U} / \mathrm{ml}$ on $\mathrm{d} 1,2,3$ and 7 , and to $\sim 100 \mathrm{U} / \mathrm{ml}$ on $\mathrm{d} 13$ and 22 (Figure 2).

Plasminogen activity at the start of the experiment was $\sim 150 \mathrm{U} / \mathrm{ml}$ (Figure 2). In the experimental glands, a nadir in plasminogen activity was observed on $\mathrm{d} 2$, 3 , and 7 of the experiment, and was followed by a return to 160 and $220 \mathrm{U} / \mathrm{ml}$ on $\mathrm{d} 13$ and 22 , respectively. In the control glands, plasminogen activity tended to increase with time; however, because of high variability, these changes were not statistically significant (Figure 2).

\section{Proteins}

In the experimental glands, the total protein concentration on d 2 and $3(\sim 55 \mathrm{mg} / \mathrm{ml})$ was 1.8 times higher than the initial concentration of $\sim 30 \mathrm{mg} / \mathrm{ml}$ (Figure 3). In the control glands, there was a tendency for protein concentration to increase during this period. On d 7, 13 , and 22 of the experiment, the protein concentration was $\sim 70 \mathrm{mg} / \mathrm{ml}$ in both the control and the experimental glands (Figure 3).

Initially, in both the control and experimental glands, $\mathrm{CN}$ (at $\sim 24 \mathrm{mg} / \mathrm{ml}$ ) constituted $80 \%$ of the total protein, whereas by d 22 (at $\sim 28 \mathrm{mg} / \mathrm{ml}$ ), it constituted only $40 \%$ of the total protein (Figure 3). A significant increase in CN concentration (to $\sim 40 \mathrm{mg} / \mathrm{ml}$ ) was observed on $\mathrm{d} 2$, 3 , and 7 of the experiment in the experimental glands and on $\mathrm{d} 7$ in the control glands (Figure 3).

Initially, whey protein (at $\sim 6 \mathrm{mg} / \mathrm{ml}$ ) constituted $20 \%$ of the total protein, but by d 22 (at $\sim 40 \mathrm{mg} / \mathrm{ml}$ ), it constituted $60 \%$ of the total protein in both the experimental and control glands (Figure 3). In the experimental glands, the concentration of whey protein increased steadily from the first treatment, and by $\mathrm{d} 7$ of the experiment, it had reached $88 \%$ of the maximal values attained on $\mathrm{d} 13$ and 22 . In the control glands, the concentration of whey protein increased significantly only after the cessation of milking, and on $d$ 7, it was significantly lower than that in the experimental glands (Figure 3).

In both the experimental and control glands, the proteose-peptone concentration increased more than fourfold, from $\sim 2 \mathrm{mg} / \mathrm{ml}$ at the start of the experiment to $\sim 9 \mathrm{mg} / \mathrm{ml}$ at the end (Figure 3). The pattern of increase in proteose-peptone concentration resembled that described for total whey protein, namely, a steady increase from the beginning in the experimental glands and a rise that started only after the cessation of milking in the control glands.

Albumin concentration in both the experimental and control glands increased almost ninefold, from $\sim 120 \mu \mathrm{g} /$ 

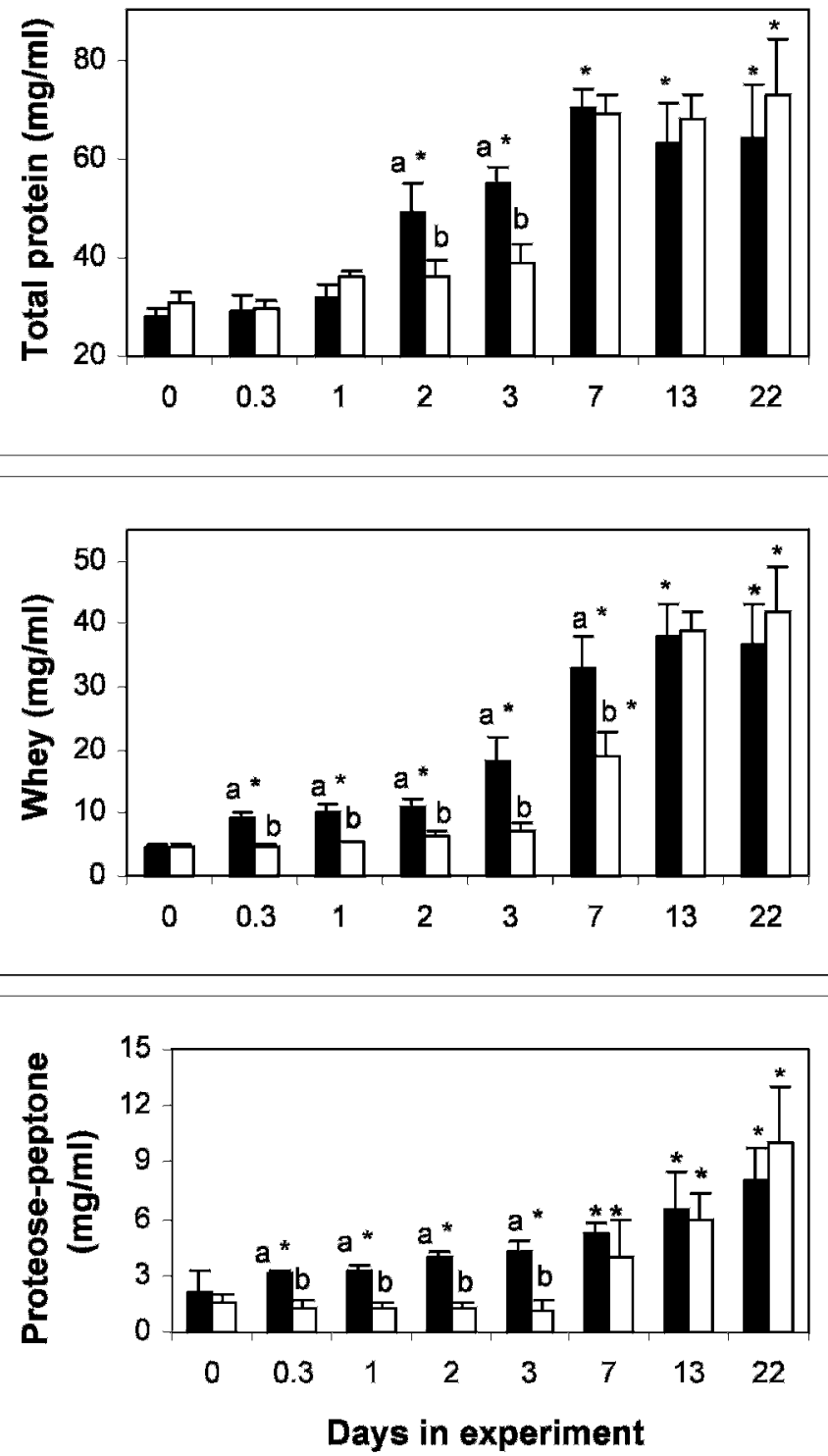

Figure 3. Effect of repeated dose of $\mathrm{CNH}$ and drying-off on total protein, whey protein, and proteose peptones concentrations in mammary secretion. *Values are significantly different from the pretreatment values $\left(P<10^{-2}\right)$. ${ }^{\text {a,b }}$ Experimental values (filled bars) are significantly different from the controls (open bars; $P<10^{-2}$ ).

$\mathrm{ml}$ at the start of the experiment to $\sim 900 \mu \mathrm{g} / \mathrm{ml}$ at the end (Figure 4). In the experimental glands, a significant increase in albumin concentration was observed after $0.3 \mathrm{~d}$, and values in the highest range were already measured from $\mathrm{d} 2$. In the control glands, a significant increase in albumin concentration (to $\sim 480 \mu \mathrm{g} / \mathrm{ml}$ ) was measured at $\mathrm{d} 2,3$, and 4 of the experiment and concentrations in the highest range from $d 7$ (Figure 4).
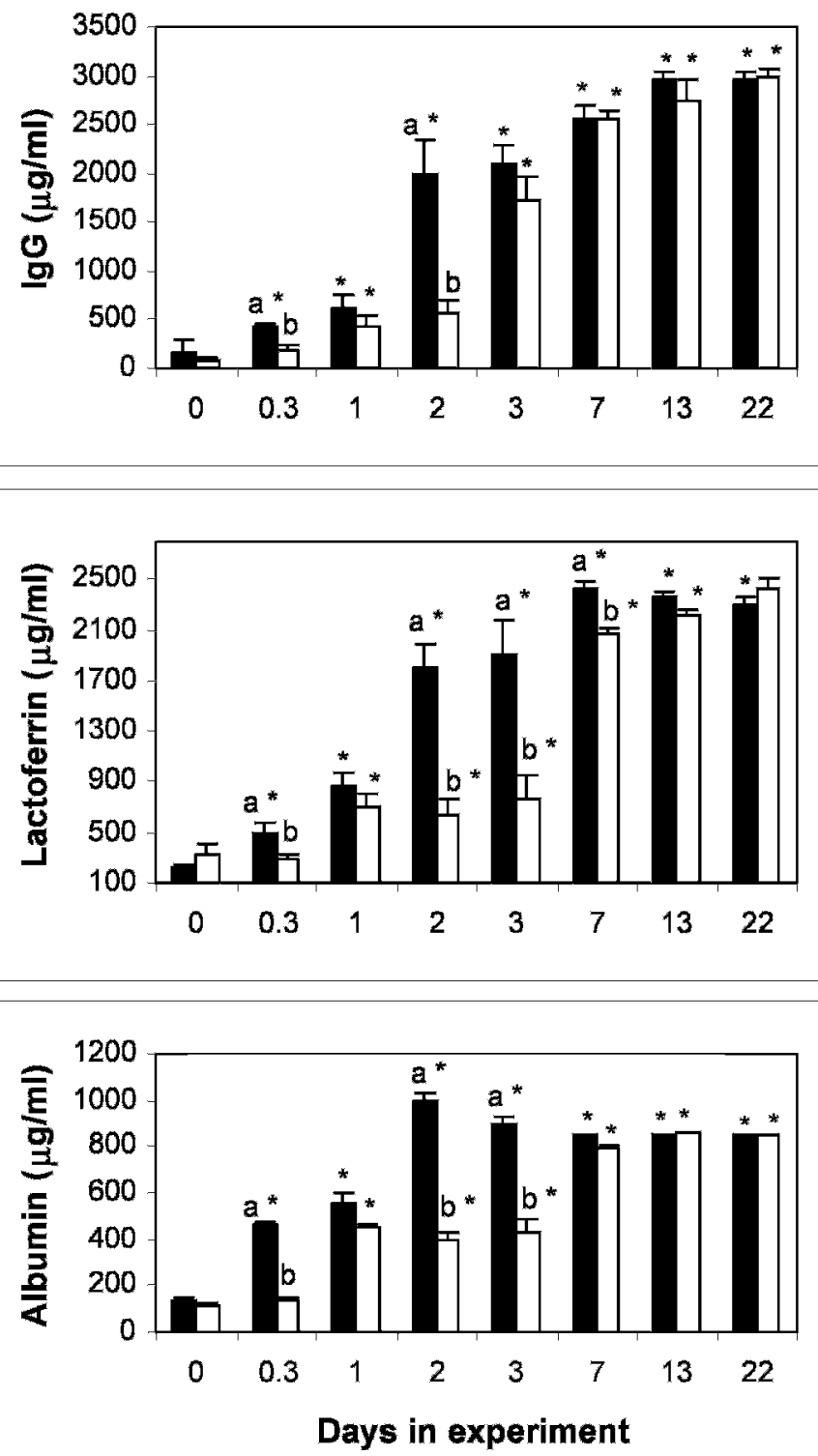

Figure 4. Effect of repeated dose of $\mathrm{CNH}$ and drying-off on immunoglobulin type $\mathrm{G}$ (IgG), lactoferrin (Lf), and albumin concentrations in mammary secretion. *Values are significantly different from the pretreatment values $\left(P<10^{-2}\right.$ to $\left.10^{-4}\right)$, a,b Experimental values (filled bars) are significantly different from the controls (open bars; $P<0.01$ ).

The concentration of Lf in both the experimental and control glands increased more than 12 -fold, from $\sim 180$ $\mu \mathrm{g} / \mathrm{ml}$ at the start of the experiment to $\sim 2200 \mu \mathrm{g} / \mathrm{ml}$ at the end (Figure 4). In the experimental glands, a significant increase in Lf concentration was observed after $0.3 \mathrm{~d}$; on $\mathrm{d} 2$ and 3 , the concentration had risen to $\sim 1900 \mu \mathrm{g} / \mathrm{ml}$, and concentrations in the highest range were measured from d 7 . In the control glands, a significant increase in Lf concentration (to $\sim 700 \mu \mathrm{g} / \mathrm{ml}$ ) 
was measured on $\mathrm{d} 1,2$, and $3, \sim 1900 \mu \mathrm{g} / \mathrm{ml}$ on $\mathrm{d} 7$, and concentrations in the highest range from d 13 (Figure 4).

The concentration of IgG in both the experimental and control glands increased 30-fold, from $\sim 120 \mu \mathrm{g} / \mathrm{ml}$ at the start of the experiment to $\sim 3000 \mu \mathrm{g} / \mathrm{ml}$ at the end (Figure 4). In the experimental glands, a significant increase in IgG concentration was observed after $0.3 \mathrm{~d}$; the IgG concentration had risen to $\sim 2100 \mu \mathrm{g} / \mathrm{ml}$ on $\mathrm{d} 2$ and 3 , and to $\sim 2500 \mu \mathrm{g} / \mathrm{ml}$ on $\mathrm{d} 7$, and concentrations in the highest range were measured from $\mathrm{d} 13$. In the control glands, a significant increase (to $\sim 500 \mu \mathrm{g} / \mathrm{ml}$ ) was measured on $\mathrm{d} 1$ and 2 , and from $\mathrm{d} 7$, the concentrations were similar to those recorded in the experimental glands (Figure 4).

\section{Macrominerals}

The fluctuations in the concentrations of total phosphorus, total calcium, and total magnesium during the first $7 \mathrm{~d}$ of the experiment resembled those of casein (Figure 5). The $r^{2}$ values of the linear correlations between $\mathrm{CN}$ and calcium (0.724), $\mathrm{CN}$ and magnesium (0.688), and $\mathrm{CN}$ and phosphorus (0.633) were highly significant ( $\mathrm{n}=288 ; P<10^{-3}$ to $10^{-4}$ ). As with $\mathrm{CN}$, by d 7 of the experiment, the concentrations of these ions were significantly higher than those on $d 0$. However, by $\mathrm{d} 22$, the phosphorus concentration had dropped markedly, and there was a clear falling trend in calcium and magnesium concentrations but without a change in $\mathrm{CN}$ concentration (Figure 5).

The total sulfur concentration in both the experimental and control glands increased almost threefold, from $\sim 9 \mathrm{mmol}$ at the start of the experiment to $\sim 26 \mathrm{mmol}$ at the end (Figure 5). The patterns of changes in sulfur concentration in the experimental and control glands closely resembled that described for the changes in whey proteins.

\section{DISCUSSION}

The difference between the responses of the experimental and control glands during the first $3 \mathrm{~d}$ of the experiment highlights two important points: First, it eliminates the possibility that the experimental glands responded nonspecifically to proinflammatory endotoxin. Endotoxins such as lipopolysaccharide may be present as contamination in the materials used and could induce some of the responses observed in the experimental glands (Olivier and Smith, 1983; Shuster and Harmon, 1991; Persson et al., 1992). Secondly, it shows that the antisecretory and inflammation-inducing properties of $\mathrm{CN}$ take effect only after hydrolysis of the mother molecules to peptides.
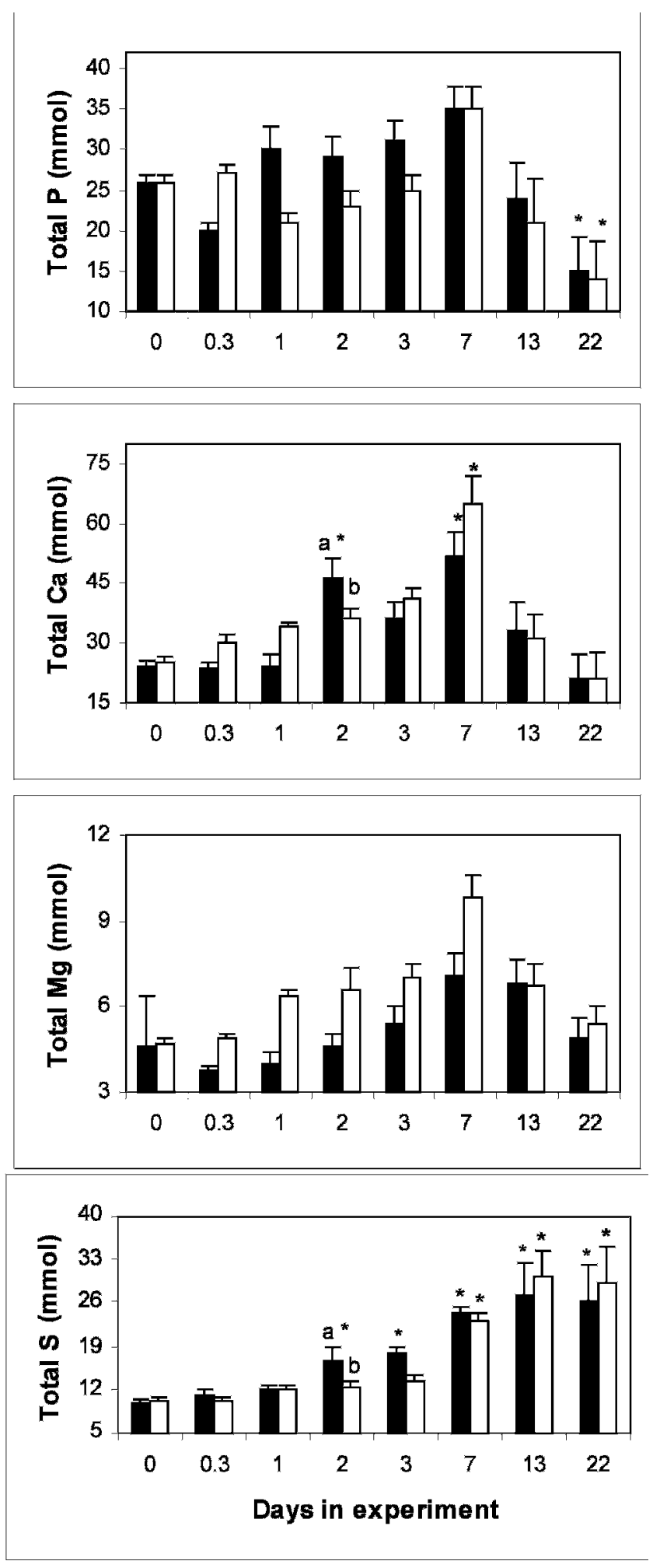

Figure 5. Effect of repeated dose of $\mathrm{CNH}$ and drying-off on total phosphorus, total calcium, and total magnesium and total sulfur concentrations in mammary secretion. *Values are significantly different from the pretreatment values $\left(P<10^{-2}\right)$. ${ }^{\mathrm{a}, \mathrm{b}}$ Experimental values (filled bars) are significantly different from the controls (open bars; $P<10^{-2}$ ). 
The process of involution of the mammary gland comprises the extensive and highly ordered sequence of ultrastructural and compositional changes that occur during the transition period between lactating and nonlactating states (Olivier and Smith, 1983; Hurley, 1989; Capuco and Akers, 1999). One of the most basic features of mammary secretion is that the total osmotic pressure of the secretion remains approximately constant and equal to that of the blood (Mepham, 1987; Holt, 1993). As lactose is the main osmotic component in milk, the secretion volume follows the changes in the secretion of lactose very closely (Shamay et al., 2000). Accordingly, the secreted fluid volume declined precipitously between 3 and $7 \mathrm{~d}$ after dry-off, in keeping with previous findings (Hurley, 1989; Noble and Hurley, 1999). In the glands treated with $\mathrm{CNH}$, the secretion rate was reduced dramatically after $1 \mathrm{~d}$ of treatment, and only a minimal amount of mammary secretion could be milked by $\mathrm{d} 3$. These results are consistent with findings on the effect of $\mathrm{CNH}$ on goats (Shamay et al., 2002).

The increase in total protein concentration in the first weeks of involution most likely reflects the reduction in the volume of mammary secretion. However, the increases in the concentrations of IgG, Lf, and proteose peptones during the first weeks of involution reflect remodulation of mammary function, in keeping with previous results in cows (Olivier and Smith, 1983; Aslam and Hurley, 1997, 1998). Treatment with $\mathrm{CNH}$ induced similar changes in the pattern of protein secretion, but these changes were induced earlier, and are also found in goats (Shamay et al., 2002).

Unilateral cessation of milking in goats ( $\mathrm{Li}$ et al., 1999) and teat sealing in mice ( $\mathrm{Li}$ et al., 1997) induced involution in the treated gland only. This specificity suggests that mammary involution is triggered by local stimuli (Capuco and Ackers, 1999; Wilde et al., 1999). Thus, the findings that $\mathrm{CNH}$ induced involution only in the treated gland, both in cows (present experiment) and in goats (Shamay et al., 2002), suggest that it serves as a local stimulus.

Tight junction (TJ) in the epithelial cells of the mammary gland forms a barrier between the systemic (basolateral) and the milk (apical sides) and prevents paracellular transport (Nguyen and Neville, 1998), but milk stasis causes the accumulation of local signals, which makes the TJ leaky (Nguyen and Neville, 1998). Because of the difference in the populations of ions in interstitial fluid and milk, when TJ are disrupted, the $\mathrm{Na}^{+}$concentration in the milk rises, whereas that of $\mathrm{K}^{+}$ declines (Nguyen and Neville, 1998). The changes in $\mathrm{Na}^{+}$and $\mathrm{K}^{+}$concentrations in the mammary secretion are consistent with disruption of the TJ at or before the onset of involution. In the CNH-treated glands, the disruption of the TJ occurred within $8 \mathrm{~h}$ after the first treatment, in keeping with the previously reported response of goats to the same treatment (Shamay et al., 2002). It is not possible, on the basis of the sampling protocol, to determine the exact time when the TJ were compromised in the cows that were induced into involution at drying-off. However, as leaky TJ reduce milk yield (Allen, 1990; Stelwagen et al., 1994; Silanikove et al., 2000), it can be assumed that TJ leakiness had been established in those glands by $\mathrm{d} 3$ after the cessation of milking, though the TJ had probably started to become leaky earlier (Stelwagen et al., 1994).

The mechanism by which disruption of TJ affects milk secretion has not been established (Nguyen and Neville, 1998). The stretching associated with milk stasis has been implicated in a mechanotransduction-signaling pathway, which, in turn, could alter both milk synthesis and TJ permeability (Nguyen and Neville, 1998). However, the continuation of udder emptying during the first $3 \mathrm{~d}$ of the experiment in cows (present experiment) and goats (Shamay et al., 2002) obviously prevented mechanical stress, indicating that decreased milk yield, in conjunction with disruption of TJ, can occur in the absence of such stress.

Silanikove et al. (2000) showed that injection of $\beta$ CN fraction 1-28 into the mammary gland in cows and goats down-regulated milk secretion in the treated gland through down-regulation of lactose secretion (Shamay et al., 2000). This finding is consistent with the hypothesis that leaky TJ reduces milk secretion in response to a reduction in lactose synthesis, which may be mediated by the cytoskeleton (Olivier and Smith, 1983; Noble and Hurley, 1999). Interestingly, the injected $\mathrm{CNH}$ contains $\beta$-CN fractions that are similar to fraction 1-28 (i.e., fractions 1-25 and 2-25; Adamson and Reynolds, 1977), and accelerates the formation of natural fractions of CN (present results, Shamay et al., 2002). It has been found in cows that $\beta$-CN fractions accumulate in the mammary gland following cessation of milking (Aslam and Hurley, 1998). Thus, we postulate that active components of $\beta$-CN may be responsible for the precipitous dry-off of mammary secretion following milk stasis.

Proteose-peptones (boiling-resistant peptides) in milk are composed mainly of plasmin-induced $\mathrm{CN}$ products (Andrews, 1983). Thus, the gradual increase in the concentration of proteose-peptones following milk stasis is consistent with the progressively increasing exposure of casein to plasmin and with the increase in plasmin activity. The notable increase in the activity of the PA-plasminogen-plasmin system following $\mathrm{CNH}$ treatment, as also found in goats (Shamay et al., 2002), suggests that casein hydrolysis is self-accelerated once a critical level of proteose-peptones accumulates in the gland. The changes in proteose-peptone concentration, 
however, were not synchronized with the changes in plasmin activity in the CNH-treated gland, as indicated by the finding that the highest concentration of proteose-peptones was recorded when plasmin activity had already dropped. Unlike the situation in the experimental glands, we did not find the expected reduction in plasminogen activity in the control glands along with the increase in plasmin activity. Plasmin activity in mammary secretions is affected by many factors, such as tissue type and urokinase type of PA (Politis, 1996), PA inhibitors (Politis, 1996), plasmin inhibitors (Precetti et al., 1997), and insulin-like binding proteins, which may increase the availability of the casein substrate (Flint et al., 2001). Thus, the steep increase in proteose-peptones concentration that was observed in both treatments from $\mathrm{d} 3$ after cessation of milking may be related to a decrease in plasmin inhibition and an increase in $\mathrm{CN}$ availability.

Roughly, two-thirds of the calcium and magnesium secreted in the milk of cows are bound to O-phosphoL-serine residues in the CN micelles (Mepham, 1987; Neville et. al., 1994), which explain the parallel fluctuations in the concentration of $\mathrm{CN}$, phosphorus, calcium, and magnesium (present experiment; Shamay et al., 2000). The increase in the total sulfur concentration with advancing involution most likely reflects the increased proportion of whey proteins, such as albumin, which are richer in sulfated amino acids than CN.

\section{CONCLUSIONS}

Injections of $\mathrm{CNH}$ into the udder induce loss of $\mathrm{TJ}$ integrity, which is followed by rapid dry-off of mammary secretion and local inflammatory response. The fact that all the treated glands resumed normal lactation after parturition supports the conclusion that we imitated natural phenomena rather than inducing a necrotic response that would irreversibly damage the secretory function of the udder. In several aspects (induction of inflammation and changes in milk composition), $\mathrm{CNH}$ treatment resembles studies in which the mammary gland was challenged with endotoxin and colchicine (Olivier and Smith, 1983; Persson et al., 1992). However, these treatments cannot induce complete dry-off of mammary secretion. Furthermore, Shuster and Harmon (1991) had shown that the mammary gland is partially refractory to frequent intramammary endotoxin infusions. Thus, the antisecretory effects of CNH are probably independent of its proinflammatory effects.

We had already treated more than 100 cows with $\mathrm{CNH}$, with $98 \%$ of the treated quarters being driedoff irrespective of cow's parity and stage of lactation (Shamay and Silanikove, 2002). This treatment ap- pears to be a viable tool for the following indications: 1) to reduce the agony associated with drying-off cows yielding $30 \mathrm{l} / \mathrm{d}$ or more milk, 2) to dry the secretion in quarter with SCC so high that it negatively affects the whole tank milk quality, which allows to continue milking the three other quarters for the rest of the lactation cycle, and 3) to eradicate from infected glands several types of bacteria that cause subclinical and clinical mastitis.

\section{ACKNOWLEDGMENTS}

The authors thank Prof. Floyd Schanbacher from the Ohio State University for donating lactoferrin antibodies and the Cattle Breeder Association of Israel for their support.

\section{REFERENCES}

Adamson, N. J., and E. C. Reynolds, 1997. Relationships between degree of casein hydrolysis and phosphopeptide release. J. Dairy Res. 64:505-514.

Allen, J. C. 1990. Milk synthesis and secretion in dairy cows with milk composition changed by oxytocin. J. Dairy Sci. 73:975-984.

Andrews, A. T. 1983. Proteinases in normal bovine milk and their actions on caseins. J. Dairy Res. 50:45-55.

Aslam, M., and W. L. Hurley. 1997. Proteolysis of milk during involution of the bovine mammary gland. J. Dairy Sci. 80:2004-2010.

Aslam, M., and W. L. Hurley. 1998. Peptides generated from milk proteins in the bovine mammary gland during involution. J. Dairy Sci. 81:748-755.

Athie, F., K. C. Bachman, H. H. Head, M. J. Hayen, and C. J. Wilcox. 1997. Milk plasmin during bovine mammary involution that has been accelerated by estrogen. J. Dairy Sci. 80:1561-1568.

Capuco, A. V., and R. M. Akers. 1999. Mammary involution in dairy animals. J. Mammary Gland Biol. and Neoplasia 4:137-144.

FitzGerald, R. J. 1998. Potential uses of caseinophosphopeptides. Int. Dairy J. 8:451-457.

Flint, D. J., E. Tonner, C. H. Knight, C. B. A. Whitelaw, J. Webster, M. Barber, and G. Allan. 2001. Control of mammary involution by insulin-like growth factor binding proteins: role of prolactin. Livest. Prod. Sci. 70:115-120.

Holt, C. 1993. Interrelationship of the concentrations of some ionic constituents of human milk and comparison with cow and goat milks. Comp. Biochem. Physiol. 104A:35-41.

Hurley, W. L. 1989. Mammary gland function during involution. J. Dairy Sci. 72:1637-1646.

Kummer, A., D. D. Kitts, E. Li-Chan, J. N. Losso, B. J. Skura, and S. Nakai. 1992. Quantification of bovine IgG in milk using enzymelinked immunosorbent assay. Food Agric. Immunol. 4:93-102.

Li, M., X. Liu, G. Robinson, U. Bar-Peled, K. U. Wagner, W. S. Young, L. Hennighausen, and P. A. Furth. 1997. Mammary-derived signals activate programmed cell death during the first stage of mammary gland involution. Proc. Natl. Acad. Sci. USA. 94:3425-3430.

Li, P., P. S. Rudland, D. G. Fernig, L. M. B. Finch, and C. J. Wilde. 1999. Modulation of mammary development and programmed cell death by the frequency of milk removal in lactating goats. J. Physiol. London. 519:885-900.

Mepham, T. R. 1987. Physiology of Lactation. Open Univ. Press, Milton Keynes, UK.

Neville, M. C., R. P. Keller, C. Casey, and J. C. Allen. 1994. Calcium in human and bovine milk. J. Dairy Sci. 77:1964-1975.

Nguyen, D. A. D., and M. C. Neville. 1998. Tight junction regulation in the mammary gland. J. Mammary Gland Biol. and Neoplasia $3: 233-246$. 
Noble, M. S., and W. L. Hurley. 1999. The effects of secretion removal on bovine mammary gland function following an extended milk stasis. J. Dairy Sci. 82:1723-1730.

Olivier, S. P., and L. K. Smith. 1983. Bovine mammary involution following intramammary infusion of colchicine and endotoxin at drying-off. J. Dairy Sci. 65:801-813.

Ossowski, L., D. Biggel, and E. Reich. 1979. Mammary plasminogen activator: Correlation with involution, hormonal modulation, and comparison between normal and neoplastic tissue. Cell 16:929940.

Politis, I. 1996. Plasminogen activator system: Implication for mammary cell growth and involution. J. Dairy Sci. 79:1097-1107.

Precetti, A. S., M. P. Oria, and S. S. Nielsen. 1997. Presence in bovine milk of two protease inhibitors of the plasmin system. J. Dairy Sci. 80:1490-1496.

Persson K., A. Carlsson, C. Hambleton, and A. J. Guidry. 1992. Immunoglobulins, lysozyme, and lactoferrin in the teat and udder of the dry cow during endotoxin-induced inflammation. J. Vet. Med. Ser. B. 39:165-174.

SAS. 1988. User Guide: Statistics, Version 6 Edition. SAS Inst., Inc., Cary, NC.

Shamay, A., and N. Silanikove. 2002. Method and pharmaceutical composition for disrupting lactation in mammary gland and for treating and preventing mastitis. US Pat. No. 6,391,849 B1.

Shamay, A., F. Shapiro, H. Barash, I. Bruckental, and N. Silanikove. 2000. Effect of dexamethsone on milk yield and composition in dairy cows. Ann. Zootech. 49:343-352.

Shamay, A., F. Shapiro, S. J. Mabjeesh, and N. Silanikove. 2002. Casein-derived phosphopeptides disrupt tight junction integrity, and precipitously dry up milk secretion in goats. Life Sci. 70:2707-2719.

Shapiro, S., A. Shamay, and N. Silanikove. 2002. Determination of lactose and D-galactose using thio-NAD instead of NAD. Int. Dairy J. 12:667-669.

Shuster, D. E., and R. J. Harmon. 1990. Enzyme immunoassay of bovine lactoferrin and serum albumin in acid precipitated and ultracentrifugal wheys. J. Dairy Sci. 73:3104-3111.

Shuster, D. E., and R. J. Harmon. 1991. Lactating cows become partially refractory to frequent intramammary endotoxin infusionsrecovery of milk-yield despite a persistently high somatic-cell count. Res. Vet. Sci. 50:272-277.

Silanikove, N, A. Shamay, D. Shinder, and A. Moran. 2000. Stress down regulates milk yield in cows by plasmin induced $\beta$-casein product that blocks $\mathrm{k}^{+}$channels on the apical membranes. Life Sci. 67:2201-2212.

Sorensen, A., D. D. Muir, and C. H. Knight. 2001. Thrice-daily milking throughout lactation maintains epithelial integrity and thereby improves milk protein quality. J. Dairy Res. 68:15-25.

Stelwagen, K., S. R. Davis, V. C. Farr, S. J. Eichle, and I. Politis. 1994 Effect of once milking and concurrent somatotropin on mammary tight junction permeability and yield of cows. J. Dairy Sci. 77:2994-3001.

Vernon, F. K., Jr., and R. W. Bernlohr. 1997. A new spectrophotometric assay for protein in cell extracts. Anal. Biochem. 82:362-371.

Wilde, C. J., C. H. Knight, and D. J. Flint. 1999. Control of milk secretion and apoptosis during mammary involution. J. Mammary Gland Biol. Neoplasia 4:129-136. 